\title{
Viewpoint
}

\section{Sustainable rural development in England: policy problems and equity consequences}

Despite considerable lip service being given to the importance of sustainable development in English public policy (Defra, 2011) for both urban and rural areas (Ecorys, 2008), two United Kingdom Government policy sets - spatial planning policy and economic development policy - have served to inhibit rural sustainable development on the ground.

\section{Spatial planning policies and the rural 'no development' ethic}

The dominant ethos of spatial planning policies since the war has been to protect the countryside. Despite the proposals in the Coalition Government's Localism Bill, still going through Parliament at the time of writing and considered further below, this ethos still remains in force today. Two strands within this policy set have impacted on sustainable rural development. The first is that national planning policy guidance about the rural economy has been weak and ambivalent whilst planning policy guidance about rural housing has been strong and restrictive. Successive Planning Policy Statements about the rural economy (PPG/PPS7) for more than 20 years (the extant ones of which are cited below) have acceded to the need for a modest amount of economic development but in tandem, have stressed:

"the need to protect the wider, largely undeveloped countryside (from development), for the benefit of all" (PPS7, 5) (DCLG, 2004)

Rural housing policies (PPG/PPS3), on the other hand, have been more assertive. They should be driven by: 
"affordable housing and rural exceptions policy in the context of general polices of restraint" with housing to accommodate "households who are either current residents or who have an existing family or employment connection" (PPS3, 30) (DCLG, 2011b).

These priorities are the wrong way round. For sustainable rural development, there need to be stronger polices about where people are to work before considering the housing that should most appropriately follow such work. If housing development is not allowed in rural areas, then sustainable development cannot ensue. If housing is allowed in rural areas only where there are existing employment connections, then opportunities for employment will ossify.

The second policy strand compounds this problem for achieving rural sustainable development. All Planning Policy Statements point to the fact that sustainable development should, in fact, be urban. This has three elements. The first is to reduce the need for travel (PPG13, 3) (DCLG, 2011a), particularly by car (PPG 13, 4), to make it easier for people to access workplaces, shopping and services (PPG 13,6) to increase the use of public transport (PPS1, 27viii) (DCLG, 2005), to encourage more walking and cycling (PPG13, 5) and to reduce carbon emissions from transport (PPS3, 37) (DCLG, 2011b). All of this should be used to manage patterns of urban growth (PPG1, 27, vii).

A second 'urban' element of sustainable development is about increasing development densities. This is a general planning principle (PPS1, 27 viii) but is a particular emphasis for housing development (PPS3, 47). The third 'urbanising' strand is concerned to maximise development on already developed (Brownfield) land (PPS1, 27, viii). It is considered that as well as maintaining high development densities, this approach will ensure access to jobs, services and community facilities (PPS3, 36) as well as protecting undeveloped (Greenfield) areas. 
Thus, spatial planning polices residualise the rural as a theatre for sustainable development by defining such development as territorial rather than systemic, ignoring all of the natural resource advantages of rural areas (food, timber, energy) for achieving sustainable development goals. They make assumptions about the environmental impact of private transport (as opposed to short term problems with the internal combustion engine) and consider it axiomatic that all built development will despoil the 'natural' environment. Both of these assumptions have been robustly contested (Bannister, (2002), Taylor, (2008) Curry and Owen, (2009)).

\section{Spatial Planning and the Localism Bill 2010 - 2011.}

The Localism Bill, progressing through Parliament in the United Kingdom 2010 - 2011 session, threatens fully to overhaul this centralised top down spatial planning system. But does what it promises suggest a more optimistic future for rural sustainable development? In the spirit of the Coalition Government's 'Big Society'1 (considered further below) spatial planning is now to be retuned to localist ambitions, decentralisation, a smaller Whitehall and more involvement of local people in democratic engagement. The Bill links planning, housing and community empowerment and would appear to offer direct reform for spatial planning in rural areas.

In sort, (and the Bill is anything but - 2 volumes, 406 pages) the parts of the Bill impacting on sustainable rural development give greater powers to councils, neighbourhoods and local communities over housing and planning decisions. Communities can seek to take over local services and will have a right to buy public buildings for community or social uses.

\footnotetext{
${ }^{1}$ The Big Society approach is about improving people's quality of life through working together and taking responsibility for the common good. It is about achieving collective goals in ways that are more diverse, more local and more personal (Cameron D, 2011).
} 
Specifically for spatial planning, all of the National Planning Policy Statements (more than 20 of them) will be collapsed into a single National Planning Framework, Regional Spatial Strategies will disappear and local communities will be able to develop and implement their own neighbourhood plans, which will be approved if they receive more than $50 \%$ of the votes in a referendum. Neighbourhood development orders (a community right to build) will allow communities to approve development without requiring normal planning consent (again, if the majority of the community approves), and a Community Infrastructure Levy will allow councils to charge developers to pay for infrastructure. Some of the revenue will be available for the local community. The Secretary of State will retake charge of the final decision on major infrastructure proposals of national importance and some form of Local Plan will replace the current Local Development Frameworks.

There has been much contemporary comment in the press about the fine detail of this Bill and how it might operate. Beyond the fine detail, however there are some underlying principles that merit consideration in terms of its consequences for sustainable rural development. Certainly, rural areas have a head start in 'localism' in spatial planning. The traditions of developing Village Design Statements, Parish Plans, Rapid Rural Appraisals, Village Appraisals and the like since the early 1990s have had no real urban equivalence (BDOR (2006), Gallent et al, (2007), Owen et al (2009)). This bodes well for certain villages, but not for those who have not indulged in such exercises historically.

In reviewing the Bill against the status quo outlined above, however, the 'fallacy of reversibility' is worthy of note: swapping one policy for its opposite does not necessarily lead to the opposite results. Thus, more than 60 years of top down spatial planning (with little local distinctiveness) is to be 'flipped over' to a predominantly bottom-up approach that could undermine the co-ordinating framework offered by a more strategic level of planning (Owen, 2011). Whilst the Regional Strategies alone were too blunt an 
instrument with nothing below them, neighbourhood plans are likely to be headless instruments without anything above them.

How will hundreds of contiguous neighbourhood plans deal with transport and accessibility matters that inevitably require joined-up analysis and proposals? How will contradictions between neighbourhood plans be resolved in the context of an uncertain relationship between a statutory development plan and the constituent neighbourhood plans? If the preparation of neighbourhood plans is patchy (as even Ministers have conceded will be the case), how and by whom will spatial planning decisions be taken for those neighbourhoods that do not have a plan?

Principles also arise in the ability of local rural communities actually to resist development. Local communities are likely to be able to prevent as well as propose the building of both affordable homes and market housing in rural settlements. This will 'preserve' the existing 'beauty' of the settlement as well, of course, as keeping house prices high through restrictions in supply. This resistance may well also extend to opposing job creating developments which are at the core of rural sustainability. Development that supports employment is crucial, but where should it go, how should it relate to other kinds of development and who should decide on its location?

Perhaps the most significant consequence of the Localism Bill, however, will be how its benefits will be distributed across society in general and rural society in particular. This equity issue is at the core of sustainable development and is considered further below.

\section{Rural economic development policies}

Rural economic development policies have been considered fully by the author elsewhere (Curry, 2010). In short, four different policy strands have served to confuse rural economic purpose, particularly in relation to sustainability. The first of these, concerned 
to increase GVA productivity and growth, has dominated at the national level for some considerable time (Treasury et al., 2006) with specific rural exhortations (Defra, 2005). At the same time, from the Local Government Act 2000 (Office for Public Sector Information, 2000) all local authorities have been required to pursue notions of wellbeing for 'local prosperity' (the Treasury and ODPM (2003), page 5), although this can be interpreted by local authorities individually in different ways. Thirdly, in European rural policy in particular, endogenous development has been a driving force for English rural areas, through successive LEADER programmes and the second pillar of the Common Agricultural Policy (CAP). ((Ray (2000), Dwyer, et al (2008)). Fourthly the first Pillar of the CAP provides income support to farmers through both supported prices and direct payments. This support actually works against productivity objectives as it discourages both efficiency and innovation (South West Farming and Food, 2006).

Government oscillates between these, not least in its consideration of spatial planning policies and sustainable development. Its consultation document for the new version of PPS4, planning for prosperous economies in 2009 (DCLG, 2009a) the planning system was to work in service of increases in GVA productivity in both rural and urban areas. The final version (DCLG, 2009b) was effectively the opposite: it would use economic development to limit carbon emissions minimise climate change impacts and traffic impacts and have a positive impact on social inclusion and local employment. The name changed to planning for sustainable growth, a term that the Sustainable Development Commission (Jackson, 2009) considers an oxymoron.

The Coalition Government offers no less ambiguity. Economic growth is the fastest way out of recession, but productivity is not a priority. The Treasury's (2011) only consideration of productivity on its web site is nothing more than the following:

"Enterprise \& productivity: our web content was reviewed and amended following the 2010 General Election to remove information related to the previous administration." 
It would appear that growth under the Coalition government is to be achieved by sustainable development, the province of the environment, food and rural affairs department, rather than any economics ministry (Defra, 2011). The oxymoronic nature of 'sustainable growth' may be less problematic for the Coalition Government as it abolished the Sustainable Development Commission in its early-term 'bonfire of the quangos'.

But is the notion of economic growth ('sustainable' or otherwise) really compatible with sustainable rural economies? The Sustainable Development Commission (Jackson, 2009, page 15) clearly believes not:

"Debt-driven materialistic consumption is deeply unsatisfactory as the basis for our macro-economy. The time is now ripe to develop a new macro-economics for sustainability that does not rely for its stability on relentless growth and expanding material throughput"

Slee (2008) also undertakes a persuasive analysis: growth is ultimately unsustainable because it uses up the world's resources and increases the inequality of wealth. There is a long economic tradition of these critiques. More than 40 years ago Mishan (1969), examined the consequences of economic growth on human well-being. In very simple terms, growth, firstly he concluded, leads to an irretrievable loss of natural capital not only increasing the scarcity of non-renewable resources but having considerable negative environmental externalities. Secondly all of his empirical evidence suggested that growth tended to increase wealth inequalities through shifts in the ownership of resources into fewer hands.

Slee (2008) also offers a good critique of the value of growth in the first place. He examines the work of earlier marginal utility theorists (Scitovsky (1976), Hirsch (1976)) 
to suggest that increases in wealth associated with growth do not, after relatively low levels of income, lead to increases in personal marginal utilities ('happiness'). More than 50 years ago this was the thesis of Galbraith (1958) in his critique of America's 'Affluent Society'.

These enduring economic propositions have been given renewed impetus with Layard's (2005) economic evaluation of happiness where, in confirming Galbraith's earlier thesis, he is even able to suggest that increasing wealth can cause reductions in happiness because of the burdens of responsibility it can confer. But it is perhaps Mishan's earlier notions of the capacity of growth to exacerbate wealth inequalities that is of significant relevance to rural areas. And here, Wilson and Picket's (2010) 'Spirit Level' is again persuasive in the contemporary context. They provide a range of evidence to suggest that that on the whole it is the more equal distribution of wealth rather than its creation per se that lead to more successful, sustainable, societies. This notion of equity is now considered as a linking mechanism between spatial and economic policies for rural areas.

\section{Equity and rural sustainable development}

The pursuit of more equal societies is one of the pillars of sustainable development from an economic growth critique. Does the pursuit of more devolved decision-making to local communities exhorted in the Localism Bill further this goal? Intuitively, the devolution of power seems to suggest an increased equality of opportunity, but of course, not all local communities have equal abilities to exploit these new opportunities and the shift of 'power' from the central state to the community also shifts the cost burden of governance towards the local community.

Thus, localism will be exploited most by the most able, educated and articulate at the expense of those who are less capable of making their voice heard. And because the localism agenda is designed to improve people's lot, it is likely to be those who reap 
most of the benefits of localism who will need them least. And these developments might take the form of new community assets or of 'defense localism' (Winter 2003) - the ability to resist development, for example. This 'inequality of ability' is likely to impact both across different communities (creating a new geography of the haves and have nots) but also within communities where there is the potential for the most powerful and vocal sections of the community to bring about possibly unrepresentative outcomes, particularly in respect of vetoing development.

And such inequalities are likely to be driven more by access to knowledge, information and skills than to material wealth per se. Those who have the ability to produce neighbourhood plans that will remain robust under legal challenge will benefit over those who have not. And the support of the voluntary sector in the provision of such expertise is coming under increasing strain in the wake of reductions in voluntary sector funding.

Further, many of the spoils of both localism and the 'Big Society' are on offer through some form of 'competitive bid' process, where the distributional consequences are at their most extreme: the most able are invariably the winners (Curry, 2011). Thus the Office for Civil Society (2011) offers a stream of competitive grants under the Giving White Paper: $£ 10$ million here for Big Society Innovators; $£ 34$ million there for those whose 'giving' is innovative. Some $£ 24$ million also is available too through the Social Action Fund to persuade people to be more actively involved in their communities.

The equity consequences are at their most stark when competitive bidding is coupled with the need for matched funding. It is now not just access to information and skills that are a prerequisite for success but also to material wealth. The Community First fund, for example, will match-fund neighbourhood initiatives with a pot of $£ 30$ million and will put a total of $£ 50$ million into community grants, as long as twice this amount can be levered by 2015 as a result. The rich get richer. 
In this complex array of initiatives, none of which actually achieve anything of themselves and appear not to be set in a prescriptive policy locus, it is hard not to fear that the already most privileged will benefit the most.

\section{Conclusions}

So, for sustainable rural development, considerations of a more equal distribution of resources and opportunities needs to be developed though both spatial planning and economic development polices, without a prerequisite for inexorable growth.

Development for the creation of jobs and thence appropriate housing, needs to displace an ethos of no development in rural areas, with human welfare at its core rather than just the natural environment. Spatial planning needs to be locally distinctive but not within a strategic vacuum. Slee (2008) suggests that thinking about the relocalisation of work, energy production, food production and the use of leisure time in a 'non-growth' context will do much to achieve this. In more general terms, Layard (2005) stresses the need to redistribute income to where it will make the most difference, to discourage selfdefeating work but to secure purposeful work for all, possibly through sharing available work and improving the work/life balance. He suggests that we should pay greater attention to mental health and to economic systems that maximise social or community well being rather than private wealth, making the most of local assets.

And rural areas seem to offer some potential for the development of such principles. Independent of (and sometimes despite) government policy exhortations local asset based developments are enjoying considerable rural popularity (Carnegie Trust Rural programme, 2009) and the Market Towns Movement is adopting many of the principles of endogenous development in producing locally sensitive development plans for economic regeneration (Caffyn, 2004). The Transition Towns Movement, too, has these sustainable development principles at its core and is developing into urban areas form its rural genesis (Hopkins, 2008). That these movements are taking place outside of any 
governmental policy framework is in some ways encouraging. Whist national governments continue to fight the 'wealth' and 'growth' problems of the past, it is heartening that rural communities themselves can exemplify more sustainable ways of developing.

\section{References}

Banister D. (2002) Transport Planning, London, Routledge

BDOR (2006) A Exciting Future for Community Plans, report to South West ACRE Network and Market and Coastal Towns Association.

Cameron D (2011) PM's speech on the Big Society, February. http://www.number10.gov.uk/news/pms-speech-on-big-society/ Accessed October 3, 2011.

Curry NR (2010) The incompatibility of economic development policies for rural areas in England. Local Economy, 25(2), 108 - 119, March

Curry NR (2011) Transactions costs in rural decision-making: the case of funding and monitoring in rural development in England. Public Administration, in press.

Curry NR and Owen S (2009) Rural Planning In England: A Critique Of Current Policy Town Planning Review, 80 (6), 575 - 596,

Department for the Environment, Food and Rural Affairs (Defra) (2005) Defra classification of local authority districts and unitary authorities in England: An Introductory Guide, Defra: London, July. 
Department for Environment, Food and Rural Affairs (2011) Mainstreaming sustainable development - the Government's vision and what this means in practice. February, the Department.

Department of Communities and Local Government (2004), Planning Policy Statement 7: Sustainable Development in Rural Areas, August, DCLG, London.

Department of Communities and Local Government (2005), Planning Policy Statement 1: Delivering Sustainable Development, January, DCLG, London.

Department for Communities and Local Government (2009a) Consultation paper on a new Planning Policy Statement 4: Planning for Prosperous Economies, May, DCLG, London.

Department for Communities And Local Government (2009b), Draft Planning Policy Statement 4: Planning for sustainable economic growth (PPS4) December, DCLG,

Department of Communities and Local Government (2011a), Planning Policy Guidance 13: Transport, January, DCLG, London.

Department of Communities and Local Government (2011b), Planning Policy Statement 3: Housing, June, DCLG, London.

Dwyer, J, Mantino, F, Schiller, S, Baldock, D, Farmer, M, Knickel, K, Prazan, J, Trantinova, M, Lewis, N, Thomson, K, Kambites, C, Kirwan, J, Tarangioli, S, Monteleone, A, Bolli, M, Clark, M, Bradley, D, Bartley, J, Hart, K, Keenleyside, C, Fagiani, P, Storti, D, Molnarova, A. (2008) Review of Rural Development Instruments: DG Agri project 2006G4-10. Final Report July 2008. European Commission (at http://ec.europa.eu/agriculture/analysis/external/rurdev/index en.htm ) 
Ecorys (2008) achieving sustainable development in rural areas: a positive response to the climate change agenda. Final report to the Commission for Rural Communities, February

Galbraith, J.K., (1958) The affluent society, Penguin: Harmondsworth.

Gallent, N., Morphet, J. and Tewdyr-Jones, M. (2009) Parish Plans and the Spatial Planning Approach in England, Town Planning Review, 79 (1), 1-29.

Hirsch, F., (1976), The social limits of growth, Harvard : Cambridge Mass.

Jackson T (2009) Prosperity without growth: the transition to a sustainable economy Sustainable Development Commission, London.

Layard, R., (2005), Happiness: lessons from a new science, Penguin; Harmondsworth Mishan, E.J., (1969), the costs of economic growth, Penguin: Harmondsworth.

Office of Public Sector Information (2000) Local Government Act, 2000, Chapter 22, OPSI, London.

Office for Civil Society (2011), the Giving White paper: http://www.cabinetoffice.gov.uk/resource-library/giving-white-paper: Big Society innovators: http://www.cabinetoffice.gov.uk/news/\%C2\%A310m-back-big-societyinnovators; the Innovation in Giving Fund: http://www.nesta.org.uk/home1/assets/features/innovation in giving fund; the Social Action Fund http://www.thesocialinvestmentbusiness.org. All accessed 29 September 2011. 
Owen, S., Moseley, M.J. and Courtney, P. (2007) 'Bridging the Gap: An Attempt to Reconcile Strategic Planning and Very Local Community-Based Planning in Rural England', Local Government Studies, 33 (1), 49-76.

Owain S (2011) Rural Settlement Planning, in Curry N R and Moseley M (eds), Reflections on rural change in Britain and Europe: collection of reflective essays to mark 25 years of the Countryside and Community Research Institute, Countryside and Community Press, Cheltenham.

Ray, C. (2000) The EU LEADER programme: rural development laboratory. Sociologia Ruralis 40 (2) pp. 163-171

Scitovsky, T., (1976), The joyless economy, Oxford University Press : Oxford.

Slee RW (2008) Sustainable solutions: dreams, dilemmas, dangers, Rural Futures Conference, Rural future, Dreams, Dilemmas, Dangers, University of Plymouth, UK, April.

South West Farming and Food (2006) Farming and Food Strategy, South West Regional Development Agency, Exeter.

Taylor, M. (2008), Living Working Countryside: The Taylor Review of Rural Economy and Affordable Housing, London, DCLG.

Treasury HM and the Office of the Deputy Prime Minister (2003) Productivity in the UK 4: the local dimension, June 
Treasury HM, Department of Trade and Industry and the Department of Communities and Local Government (2006) Regional Economic Performance Progress to date, London, December.

Wilkinson R and Pickett K (2010) The Spirit Level: Why Equality is Better for Everyone, Penguin, Harmondsworth, November

Winter M (2003) Embeddedness, the new food economy and defensive localism, Journal of Rural Studies, 19(1) pp23 - 32, January 